\title{
Children's Imaginaries in the City: On Things and Materials
}

\author{
Raluca Soreanu \\ Birkbeck College, Department of Psychosocial Studies \\ r.soreanu@bbk.ac.uk \\ Address for all correspondence: \\ Department of Psychosocial Studies \\ Birkbeck, University of London \\ 30 Russell Square \\ London WC1B 5DT \\ United Kingdom \\ Iulia Hurducaș \\ PhD candidate, Sheffield School of Architecture \\ iuliahurducas@gmail.com \\ Address: \\ Sheffield School of Architecture \\ The University of Sheffield \\ Arts Tower, Western Bank \\ Sheffield S10 2TN \\ United Kingdom
}

\section{Acknowledgements}

The authors would like to thank Adrian Borda, Irina Culic, Stephen Frosh, Virgil Pop, the editors and two anonymous referees. The authors are also grateful to the children of the Railway Workers' neighbourhood and to the participants in the 'Atelierul de urbanism' (The Urbanism Workshop), Cluj-Napoca: Daniela Ana, Florin Baci, Camelia Badea, Ana-Maria Murg, Victor Perdevară, Daniel Peslari, Diana Prisăcariu, Iulia Șandor, Cristian Suciu, István Szakáts and Manuela Țuglui. This research was supported by a grant offered by the Romanian National Authority for Scientific Research, CNCS - UEFISCDI, project number PN-II-RU-PD-2011-3-0221 and by the European Union, through a Marie Curie International Outgoing Fellowship, FP7-PEOPLE-2011-IOF, project number 301787. 


\title{
Children's Imaginaries in the City: On Things and Materials
}

\begin{abstract}
:
The article is an exploration of urban imaginaries emerging through a play with materials. Starting from a complex activist exercise for reimagining the space of a park in decay, whose protagonists are children, we propose a reflection on the productivity and resilience of matter. We argue that a new materialist sociology is one that takes disappearances seriously. Capitalism renders space abstract not only through flow and circulation, but also through stillness. We follow the curious disappearances and reappearances of the park in question, tracing the mutations of urban planning, of the juridical domain, and of the everyday use of space. Finally, we analyse the making of a maquette of the park by a group of children and their alliances with activists. The maquette is a political "thing": it leads us away from an urban imaginary populated by discrete objects to an urban imaginary of depth and it reconcretises space.
\end{abstract}

Key words: children's imaginaries, radical social imaginaries, new materialism, children's participation. 


\section{Introduction}

In his writings Althusser (2006) insisted that materialism is the most difficult problem that we encounter as social thinkers. We here propose a sociology of disappearances and reappearances, as part of a new materialism of the encounter. Things are not static, but they are in constant movement. Things leak out of themselves. Things leak into invisibility. The new materialist sociology we argue for is one that takes disappearances seriously.

In the past two decades, a creative place of utterance has emerged in critical urban scholarship: it is a place defined by surpassing a firm opposition between poststructuralism (which has tended to dispense with things) and Marxian phenomenology (which has tended to substitute things for objects, and to argue that we have lost the thingness of things to objects). The productivity and the resilience of matter became the most important materialist story to recuperate (Coole and Frost 2010). Matter returned, but in its processual insistence, as matter that becomes, rather than as matter that is.

To this discussion, we add two peculiar questions. How can we tell a story of a disappearance of an urban space (here, it is the space of a park) from urban imaginaries? As we show, capital accumulation turns space invisible. How does space reappear through creative alliances of children and activists around materials? By asking these questions, we bring our contribution to a recent debate in the field of children's geographies about the politicality of studies that capture the processual dimension of action.' Some argue (Aitken 2007; Mitchell and Elwood 2012) that studies focusing on the transient, the processual, the everyday, the performative or the embodied stand the risk of depoliticising their site of research, by neglecting the material conditions of the action, or by failing to discuss the wider historical context, and its specific relations of power. In what follows, we are committed to "stay political" by firstly proposing a social history of the space we discuss (assembled from ethnographic material as well as from secondary sources) and secondly showing that what appears to be children's play proves to be a significant source for a radical rethinking of urban planning. While our argument finds important resonances with theorists working with non-representational theory (Thrift 2008) and with voices in children's' geographies drawing on this theoretical line (Horton and Kraftl 2006; Jones 2008; Kraftl 2013; Kraftl 2015), we propose our own articulation on new materialism. Firstly, we tie into the conversation Cornelius Castoriadis' ideas on the radical imaginary, and his critique of the dichotomy material/immaterial. Secondly, we rely on Tim Ingold's processual and relational 
view of action, centred on the notion of "entanglements". Thirdly, we give an ethnographic account of an entanglement between children, activists and various materials, all caught up in the political "play" of making a maquette of the park.

The place we analyse is in itself a complicated one, living across many threads of time. It is actually a former park - the Railway Workers' Park - built in the 1920 s in the town of Cluj-Napoca, in Romania, and currently found in a contentious legal state. The park is one of the "things" we go by: it is a spatial thing where capitalism makes its inscriptions, deadening it to local use. As a thing, however, it can never be fully turned into an object, it can never become stable and foreclosed, but it continues to leak out of itself.

The social history of the park we propose in the second part is one of the ways we stay political. It is also our manner of approaching the puzzle of stillness of the space we analyse, of its slipping away from everyday use. We show how capitalism renders space abstract not only through flow and circulation, but also through stillness. What happens when a whole park disappears from the urban texture? We practice a materialism that sees the state, governance and production as entwined. We tell a local story of the enduring importance of the state in maintaining regimes of capital accumulation, and the regulative structures that help reproduce them. State power is active in the crafting of a legal blur, which is in turn tied to the erasure of a space from use and from local urban imaginaries. The juridical is claimed on economic grounds: law is reduced to a set of guidelines for implementing capitalistic rationality. The legal blur produces an event of stillness in the park, which makes space itself disappear. Telling the story of the legal domain in Cluj-Napoca, as well as the story of the domain of urban planning, works as a contextualising political frame for our ethnography of the activist exercise. These domains are defined through an exclusion of children. Modernist planning is distinctively adult-centric, and it resonates with broader social-political-legal moves of construing children as dependent and of segregating them from public life (Gillespie 2013).

In the third part, we explore the partial reappearance of the park. We describe the intervention of an activist group - "Atelierul de Urbanism" (The Urbanism Workshop) - which aimed at involving the children of the neighbourhood into building a tridimensional maquette of it. To dream a materialist dream of the reappearance of the park necessarily mobilises all the layers of our urban imaginaries; and it draws in new dreamers and makers. How children's hands dream on materials, in the site we describe, is not a small resource for urban change. The problem of radical imaginaries (Castoriadis 1987) in urban scholarship cannot remain in the realm of stating their existence, or in the realm of attributing - from the 
premises - radical predicates to some of the actors (here, the children). Instead, methodological explorations are called for so as to trace radical subjectivities at work, and to trace creative alliances, rematerialising space in their sensing, crafting, weaving and moulding.

We propose an ethnography of the activist exercise, of the alliances and cohabitations of the children and activists, and of the making of the maquette. The maquette itself, as "weaved" by the children (Ingold 2000), is thus the second "thing" we assemble in the analysis. Its "thingness" unfolds in a logic that is not one of accumulation. It is a non-commodity and speaks about how things remain fungible outside the commodity form. It does not disappear into stories of what we know already (homogenous capital accumulation). It takes risks, it surprises, it co-opts. It brings the space of the park beside itself, and in so doing it rematerialises it.

What type of weavers do we discover children to be? We insist on a nonessentialist and non-utopian understanding of childhood. Children's practices are not in some magical way outside of capitalism and its modes of operations. Still, we observe a concrete difference (Gillespie 2013) in how children practice the city and in how they relate to materials. In order to be able to learn from them, the activists treat the children in their full otherness (Jones 2008), and as actors able to give different urban solutions and invent new relations between thought and life (Thrift 2005). When we speak of the children, we thus mean the embodied children of this exercise. As we see in what follows, the children's weaving of materials transports us to "the elemental" (Levinas 1978) - a dense point of matter where past touches present and future. In the children's play, there are some types of practices that make things re-appear. Firstly, there is misuse. We are taken from use value to misuse value (Brown 1998), revealing the re-materialising and re-signifying effects of displacement and disrespect to function. Secondly, there is free-weaving. The children engage in recombinatory practices that juxtapose or mesh a wide variety of materials, thus giving us access to an urban imaginary of depth.

\section{Radical Social Imaginaries and the Co-options of Materials}

What does it mean to dream of a different city? And what does it mean to make a different city? For Cornelius Castoriadis (1987), the radical social imaginary is the fundamental capacity of a society to create significations through which it brings itself into existence as a society. This capacity draws on the radical imagination of the psyche. It is a "capacity to see in a thing what it is not, to see it other than it is" (Castoriadis 1987, p.12). The unstoppable flux of forms/figures/images that 
characterises the human psyche, as Castoriadis describes it, surpasses any opposition between material and immaterial. The images of the psyche are not to be seen as immaterial entities. Image formation (both social-historical and psychic) is crucially a physical event, bringing the "alteration of material structures, an organisation or reorganisation of the body" (Klooger 2009) and of the social body. Here, Castoriadis walks us from representations to presentations. Firstly, this setting into images constitutive of presentations is never just a copy of a "real" existent elsewhere; it is not reducible to it; or determined by it. To this extent, there is always an overabundance of meaning that the radical imagination creates. Secondly, this setting into images is not confined to either language or the visual, but it is extended to any arrangement that embodies and conveys meaning.

It is time for thinkers of the urban to dream a very complicated materialist dream of the city, which follows the grammar of Castoriadis' theory, insisting that substance cannot be separated into ideal and material, with the former determining and ruling over the latter. Drawing on Castoriadis, we recuperate the radical and heterodox aspects of re-imagining the urban, on the grounds of forms/figures/images that are not merely "different" (as if in a dream which fetishises the new) but are truly "other": "To say that figure B is other than A means [...] in the first place that it cannot be deduced, produced or constructed on the basis of what is 'in' A, whether implicitly or explicitly, or on the basis of what is posited, mediately or immediately 'with' A" (1987, p.195). While we can dream different dreams of the city, it is dreams that are truly "other" that hold the promise of reconfiguring space. Here, we resonate with authors that affirm the otherness of children by virtue of the concrete differences (Gillespie 2012) in their practices. To argue for a non-essentialising perspective on childhood does not mean effacing inter-generational difference, and the alterity of children in relation to adults, which passes through the uneven power relation that traverses them (Jones 2008, p.2). As we show, it is not only children and adults that are able to act, materials act as well.

So as to affirm the radical imaginary as a "matter of matter", we draw on a new materialism of materials (Ingold 2011) and on a new materialism of the encounter (Guattari 2011). Firstly, this new materialism proposes an ecology: a radically revised thinking about organisms and their relations to their environments, formulated in terms of constant negotiations and co-habitations (Ingold 2000; Bateson 1972; Guattari 2011; Haraway 2003). What we usually call "the environment" can be seen, following Ingold (2008), as a "zone of entanglement": "within [a] tangle of interlaced trails, continually ravelling here and unravelling there, beings grow or 'issue forth' along the lines of their relationships. This tangle is the texture of the world." 
Secondly, it proposes a commitment to a processual view of this ecology, where formation intrigues us more than the final product; and the transformation of materials captivates us more than states of matter. As Klee $(1973$, p.269) writes "[f]orm is the end, death", while "[f]orm-giving is movement, action. Form-giving is life". An object seen as a fait accompli is thus just seeming-form that co-opts us in the illusion of its stability, while unfolding in a constantly forming world. The theoretical work to be done here is not to decide between reification and the death of reification, but to see how under certain historical conditions (like the predominance of economic semiotisation over other-than-economic semiotisation, characteristic to capitalistic rationality) some very enduring illusions of stability are achieved. Capital accumulation manages to contain the leakiness of things, and to make them appear to us as mere objects. The new materialism traces how supposed objects leak out of themselves and re-become "things". And things are always moving, they are "goings on" or places "where several goings on become intertwined" (Ingold 2008). What we add to this new materialism is a fascination with moments when things cross into and out of the invisible, producing certain kinds of ghostliness.

Thirdly, the new materialism cannot be envisaged plainly as giving back agency to objects, or expanding agency to encompass the world of objects. As Ingold (2008, p.12) writes, "to render the life of things as the agency of objects is to effect a double reduction, of things to objects and of life to agency". Material things, just as people, are processual: they are happening and they are necessarily part of an ecology. While Castoriadis offers an ontological frame for thinking the relationship material/immaterial, Ingold elucidates the processual quality of action.

Thinkers of the urban have lately creatively shifted their ontologies and epistemologies toward movement, networks, flows, folds, streamings, associations and indeterminacies (Amin and Thrift 2002; Doel 1999; Massey 2005; Smith 1996; Thrift 2008). In so doing, they have sought to avoid describing the urban in terms of a single ordering principle (capitalism, neoliberalism, globalisation) and the hauntings of an idea of structural exteriority and of causes that produce their effects "at a distance" (Smith and Doel 2011). Capital-centric stories of the urban construe a unique and homogenous time of expansion, adaptation and internalisation of a single logic (Chakrabarty 2000).

While taking immanence seriously, we however run the risk of "dreaming" capitalism away as a legitimate object in urban scholarship (Karaman 2012) or of depoliticising our sites of research by disregarding their material context of action (Mitchell and Elwood 2012). The disappearance of "capitalism" from our theoretical vocabularies interrupts our capacity for critique (De Landa 2000). The question is 
how to preserve the capacity of thinking capitalism, while accounting for copresences and co-emergences, and while allowing a description of the urban as an incongruent with itself, plural, and even excessive space.

The escape is bound to be a temporal one. With Althusser and Balibar (1970, p.95), we perceive that something always "runs ahead of its time". This way, we are never located in capitalism as an "expressive totality", where every part can express and be expressed in the other parts and in the totality as a whole. With de Certeau (1984, p.xix), we see how something always runs beside the main homogeneous time of capitalism. Actors exercise this beside-ness in their tactics: practices grounded in a "calculus which cannot count on a 'proper' (a spatial or institutional localization), nor thus on a borderline distinguishing the other as a visible totality." It is the task of new urban scholarship to collect alternative times, and to describe the kinds of weavings that run ahead of and beside their time.

In the midst of a near-disappearance (that of space itself), we will see how children and some alliances and entanglements between children and activists make things reappear in their thinginess and in their refigurative power. It is by following the disappearance and reappearance of things that we can find a productive escape from both Lukacs' (1971) overpowering notion of reification (of everything) and its hasty demise: the illusion that we no longer need any elucidation of the distinction between things and objects. Flows of capital do abstractise space. The capitalgovernment nexus does act to make space invisible. What is thus needed are recordings of the travels from things to objects and from objects to things. In other words, we are called to write the political biographies of the reappearance of things (including space itself) (Kopytoff 1986).

So how do things reappear at the hands of children? Thinking with Adorno (1978) we are not breaking away from reification: we remain inside an allegory of proper use and preconceived utility (Adorno 1978; Brown 1998). Adorno suspects that play might expose the secret life of things, but he cannot envisage a way out of the mirror of utilitarian consumption contained in the allegories of children's play (Brown 1998, p.953). Thinking with Benjamin (1996, p.408), the moment when objects leap out into things is traceable in children's play. Benjamin is ready to discover in children radical subjectivities whose sensuous practice (touching, smelling, moulding) becomes resignifying practice: "[i]n waste products children recognize the face that the world of things turns directly and solely to them. In using these things they do not so much imitate the works of adults as bring together, in the artifact produced in play, materials of widely differing kinds in a new, discontinuous relationship." We caution against an idealisation of childhood in the Benjaminian conception. In what follows, we are curious about all material traces 
that remain outside a utilitarian telos, and that cannot be capitalised on. In describing our group of children working on the maquette, we remain in an ethnographic position of active witnessing, participating in the entanglement of children, activists and materials, but ready to be unknowing and to be surprised by the profoundly different ways in which children place objects in relations.

\section{Privatising Public Space and the Legal Blur}

In what follows, we trace the social history of the park and we describe its disappearance as an event of stillness. The juridical domain and the domain of urban planning are key to telling our story: they produce material consequences. It is also crucial to recover the repressed and neglected histories of different urban communities and of their members. When aiming to access the experiences of children, there are significant limitations, especially when the history we wish to tell starts nearly a century ago. In this section, we draw on our ethnographic material, collected over one intense year of participating in and observing the work of a group of activists mobilised for reclaiming the space of the park for public use; our proximity to the everydayness of the neighbourhood (one of the authors had lived in the area for three years); and our access to activist projects centred on the park and its surroundings (including a project of collecting oral histories of senior dwellers in the area). We also draw on secondary sources (oral and written accounts of urban planning and property relations in socialist Romania and news reports on the political and legal decisions affecting the park); and on interviews with architects and urban planners in Cluj-Napoca. Despite these plural entries into the past times of the park, our social history is limited by the difficulties of standing outside of childhoodsociety relations, even while ethically committed to exploring the worlds of children. Matthews (2005, p.272) argues that even well-intentioned research is heavily immersed in the power relations specific to its context of production, and thus it "promulgates and perpetuates a particular way of seeing, which is often adultist, exclusionary and oppressive". While we attempt to be reflexive about our adultist bias when collecting and when assembling our story, the "archives" we looked at in the domains of law-making and urban planning are carriers of traces authored by adults and directed to other adults. Modern city planning is predicated on the exclusion of children and on their segregation to places that remain under the control of adults. A political analysis of children's worlds does not only record the spaces where they are present, but also the politics of their absences. 
The Railway workers' neighbourhood is a working class neighbourhood that emerged in the second half of the 19th century in the city of Cluj. It grew outside the official city limits. Neither within, nor without the city, its social imaginary is marked by a recurrent centre-periphery image. Dwellers spoke to us of other more beautiful or notable neighbourhoods that belonged to "the city" more than theirs. In the 1920s, the space came to be used as cattle market, thus challenging the centreperiphery relation. The cattle market, linked to the slaughterhouse nearby, was the house of the trading and conviviality rituals of a heterogeneous population comprising Jews, Romanians, and Hungarians. Most of them owned their shops, grew vegetables or raised cattle to be traded at the market. Dwellers' stories of the first decades of the post-war period contradict common historical narratives that see the park as simply replacing the cattle market in the 1920s. The spatiality of the market remained versatile: it functioned as a football pitch for the neighbourhood on Sundays; or as a place where the circus would set in.

With moves of ethnic purification and with the spatial and macroeconomic planning during the second World War and after, the ethnically heterogeneous texture of the neighbourhood, as well as the complex use of the space were partly overwritten by the park-proper. During communism, the space was turned over to the state-owned Railway Company. The workers living in the area were mobilised toward building the park, in the name of their belonging to a socio-professional category. As part of an attempt at subordinating all aspects of public and private life to the work place, the refurbishment of the park in the 1970s (the last one to date) transformed the space into an amusement park for the workers and their children. The whole park became a huge playground, with playing structures, swings and benches. A steam-engine train became the emblem of the park. It symbolically brought together work and leisure cultures.

After 1989, with the fall of communism, the park was left in decay. The passage of time made its imprints on the steam-engine train, the playing structures, and the benches. Throughout the 1990s, the space was taken over by greens. It was used by a few of the children of the neighbourhood, who would still venture inside.

As our (adult) dwellers recount, until the end of the 1990s, the space of the park had its own liveliness, it was given to use. Even if leisure was recoded through the labour of a socio-professional group, as defined by state socialism (here, the railway workers), the locals still remember the rituals of "making things together", the feeling of being co-opted in the life of the park, or in the building effort necessary for its materialisation. The park was also hosting festivals - a clever temporal "stealing away" from the homogeneities of bureaucratic rule and retrieving the space to enjoyment. 
So how did the park end up falling out of local spatial imaginaries? Adults find it hard to integrate it in the everydayness of their neighbourhood and children visit it less and less. It has become still. This event of stillness can be deciphered as a postsocialist story about the double movement of the devalorisation of the commons and the fetishisation of private property (Petrescu 2010). But our argument goes further. A legal blur affecting the materiality and the everyday use of the park resulted from (1) the planning operations of socialism; and (2) the economisation of the juridical occurring during postsocialist capitalism. Capitalism worked locally by transforming the law into a set of guidelines for implementing a capitalistic rationality.

Within state socialism, at the end of the 1970s, planning was done with a regional perspective in mind by two major players - the Regional Council and the Regional Planning Institute. Their relations were hierarchical: political decisions were taken by the Regional Council, while planning was viewed as a technocratic extension of the political. Both institutions were adult-centric and involved no participatory practices. Throughout the 1980s, in a framework of national competitiveness between regions and between cities, the Regional Council sought to promote the regions' most valuable city, its capital, Cluj-Napoca. This was done by planning massive social housing developments, infrastructural projects, and embellishment of the city centre and of the green spaces. Most of these large-scale projects, however, remained uncompleted. In an attempt to fill the gap between the planning and execution of new projects, the Regional Council started to rely on large state-owned enterprises. These enterprises were able to redirect economic resources and to mobilise the labour needed for such works. Thus, the Railway Workers' Park, the main green space in the neighbourhood, was handed to the stateowned Railway Company for refurbishment and maintenance. We see here how socialism operated by spatially recoding leisure through labour.

The overabundance of planning laid the grounds for a strategic approach to green spaces in the city. In 1984 the Regional Planning Institute was commissioned by the City Hall to conduct a study on green spaces. This resulted in a proposition to integrate and interconnect all green spaces into an all-encompassing system (Mitrea 2010). In the first decade of postsocialist capitalism, this dream of an integrated green network was forgotten by the authorities. This "forgetfulness" was in line with the political rationality of capitalism, which now dictated the dismembering of space into smaller units that would be easier to privatise. During the profound restructuring of property that emerging capitalism brought, the Regional Council continued to act as an allocator of space units. When the state-owned enterprises were transferred into private hands, so were the green spaces previously assigned to 
them. From an active horizon of use, these spaces passed to a passive state of neglect, while awaiting their capitalization. Not only did the city lose a lot of its green spaces together with its industry, but also some of those it kept became objects of contention within the multiple legal frameworks regarding the restitution of property. ${ }^{\text {ii }}$

In the second half of the 1990s and the beginning of the 2000s, the restructuring of capital meant an ever growing tendency of treating green space as a potential source for profit. Acting through the government-economy nexus, capital claimed and traded more and more available spaces of the city for its profits. The Railway Workers' Park attracted the attention of a key player seeking to transform this park and the adjacent slaughterhouse grounds into a profitable real estate development comprising a mall, office spaces, a hotel and some sports facilities. As this project still awaits its horizon of completion, the park is sunk into absolute stillness.

Since the 2000s, international capital became a major actor in the city, and the loose legal framework was replaced by a more rigid one, centred on formal concessions and legally binding contracts. The overlaid legal concessions to local and international capital created a new regime of administering green space, based on small breakable units. At the heart of this regime there is a fantasy of capitalistic accomplishment, which overpowers other space imaginaries, and inscribes space with a homogenous time of accumulation. There is no place here for references to children's interests. Within a legal limbo, our park itself began to have a complicated and torn life. The initial concession contract - passing the space from the Railway Company to a Football Club - was annulled and the issue was shifted from the regional level to the national level. The new contract was one of association.ii The investors of the Football Club started building prior to obtaining building permits, while the juridical failed to stop these operations.

On the grounds of the park, capitalism works in hidden ways toward abstraction. In a passage that parallels the passage from concrete labour to abstract labour (Marx), concrete space is abstracted. Here, we see how a capitalistic logic is acted out as abandoning not-yet-privatised space to decay: space is transformed into a kind of ghost of itself and it is filled with death references. How so? While the legal status of the space is still an object of contention, the local authorities are letting the park be overtaken by vegetation and disappear behind the wild bushes growing on its fences; the paths, trails, and train tracks disappear under tall grass. As general decay is settling in, there is a robust change in the local imaginary of the park: in the past years there were numerous associations of death and danger weaved into people's talk of the area. A story of a dead body found in the tall grass kept returning 
to the narrations of the park. Concerned parents started to forbid their children to cross or to play in the park.

Capitalistic rationality thus acts to evict children's play from the park by operating a mutation to the social imaginary of space: it takes it from an active horizon of use to a horizon of stillness and death. Capitalism pushes out of use spaces it cannot incorporate as decisively privatised, spaces over which it has not secured juridical control, producing a particular kind of spectrality that operates through an anonymous and diffuse morbidity. Small theatrical interventions sustain this morbidity: as a gesture of compensation for the illegal cutting of trees in the park, the football club that holds the right to invest in the park made an attempt to replant some trees. Strangely, the majority of them died shortly after.

As the park fades out of the social memory of the locals, it becomes a crucial object of contention for different kinds of activism in Cluj-Napoca. While there is no consensus among activist groups with regard to the desirable future of the park, the vectors organising this field of contestation tell an important story. Activist groups strengthen their local actorness precisely by acting in and around the park, by negotiations and acts of resilience. The legal blur in itself thus creates some entry points into re-materialising and de-ghostifying the space. As activists define their way of acting, they encounter the main players of urban planning. Within the architectural field, perpetuating the technocratic view of the profession that characterized the socialist era, the focus goes to the design of space, rather than its political reclaiming.

Within the activist field positions are clustered around two main approaches. The first one is a strategic one (de Certeau 1984), operating in the field of policy making and aiming to create strong ties to local authorities and the press; it imagines a negotiated form of ownership between the private investor and the local authorities, as a guarantee for the future public usage of the park. In this approach, the idea of children's participation is a "thin" and often tokenistic one (James and James 2004). To put it in Warshak's (2003) words, it is driven by "the enlightenment rationale": adults listen to children so that they can improve their decisions made on children's behalf. The second one is a tactical approach (de Certeau 1984) that envisages a bottom-up participatory process of reclaiming the park, it develops bonds with the local community, and it sees children as capable of valuable urban insights. It is a "thick" idea of participation. In what follows, we trace a tactical exercise. 


\section{Children's Urban Imaginaries and Materials at Work}

The ethnographic account that follows is a co-authored one: an architect and a sociologist, both present on the site in a double quality of activists and observers, are (modestly) witnessing the preparation and the unfolding of a participatory exercise involving children. We caution from the start that for us the exercise and our (partial) account of it are two different things. Not all the aspects of the plurisensorial appeals of the play with materials fit easily into a written form. Furthermore, our ethical standpoint is not one of representing the children we observed, or translating their work for a larger audience. Instead, in this section, we offer a description of the making of the maquette, in the spirit of a sort of ecological empiricism: we are curious about what type of actors and materials hold up together in alliances and entanglements. We are interested in the ways adults, children, and materials cohabit emergent spaces (Mannion 2007).

Between the 30th of September and the 1st of October 2012, an informal activist group in Cluj-Napoca, "Atelierul de urbanism" (The Urbanism Workshop) reuniting sociologists, anthropologists, activists, an artist, a permaculture practitioner, and an architect - organised a participatory exercise of urban reimagining centred on the Railway Workers' Park. The exercise had as main actors the children living in the park area. The activists were animated by a bottom-up "thick" participatory vision. They converged in their interest in working with children, and in experimenting together with materials. The activists met for over half a year, preparing the intervention minutely. They gathered the children through a sort of snowballing technique: in their exploration of the area, they spoke to some children and to some parents, who afterwards tied into the conversation yet other dwellers.

There were two phases in the activist exercise: first, a playful sensorial exploration and appropriation of the space, where the geographies of adults met the geographies of children, learning from each other about the park; second, the building of a tridimensional maquette of the park, where figures and images of the park found their materialisations. The maquette was presentational (Castoriadis 1987), instead of merely representational: it expressed children's signification about the urban in a way which surpassed any intention to record images of a pre-existing place. It created a surplus of signification in the horizon of urban imaginaries. It also acquired a life of its own, by attracting new presences in its negotiations through materials.

In the first phase, the children ${ }^{\text {iv }}$ gathered in the park and met the activists. Some of us had known each other from before. We played a game of weaving a thread among us, which already installed a sense of familiarity. The activists 
proposed to the children a plurisensorial circuit of the park. It is important to note that the activists did not attempt to efface their own presence from the site, or aim for some illusionary invisibility. They conceived of the "stops" on the circuit of the park as stimuli, with which the children could associate in myriads of ways. Their thinking was relational, aiming at construing alliances and making things together. Space was gradually discovered and appropriated through play and negotiation with materials, not pre-represented. The activists did not show the children any maps or plans of the park, thus avoiding the constitution of an external point of perspective. What happened in the end is that several geographies of the park met. The activists had their own (flexibly defined) circuit, and their own "landmarks" of the park (having to do mostly with their research into the history of the park and their interest in its different temporalities); but the children had their own alternative "landmarks" (having to do with the places they regularly cross or use as playground, despite the park being officially unusable).

The circuit started at the dried-up fountain in the central alley, and it went on to the former Train Station, which used to be a very animated spot. The activists told the children about the past times of the amusement park and its train. The next stop was near the synthetic football field, which the sports club had built without a permit. The group of children and activists reclaimed the area by weaving strips of fabric on the tall fence, creating colourful "drawings". Again, the children were introduced to the story of the intrusive and privatised football field. They afterwards followed the railroad track, which runs parallel to a river. On the river banks the explorers embarked into an olfactory exercise: finding a particular plant by its smell. This is an area the children were most excited to discover, as in their playing they often avoided it, afraid of the tall grass. Finally, they wrote their wishes for the park on stones that they left behind, to be read by passers-by. By the end of the exercise, both the activists and the children knew much more about the park. The activists were consistent in moving freely between the material and the immaterial of the park, combining various physical landmarks with political stories and evocative images of different times of the park, with games, and with written words.

In the second phase, the children were taken to an exhibition space near the old fortified walls of the city, the Tailor's Bastion, where a great variety of materials were made available to them: plants, chestnuts, tree bark, modelling clay and wax. Hours of intense negotiations with materials followed. The making of the maquette is an episode of co-option by materials, which enable us to see the relationship between lived urban space and its creative arenas for being refigured. Ultimately, the maquette is an emergent surprising materiality, without ceasing to be a dense semiotic object. Here, sense is made precisely through the conglomerate of 
materials, through the shapes they are stabilised into, and through spatial relations between the negotiated elements. Things mean in their materiality and in their immediate locality, not at a distance. There is a "more-ness" in the meanings inscribed in the maquette as compared to a potential bidimensional map of the park, carrying the gesture toward exactitude of the urban planner. By giving in to the lure of concreteness brought by the wide variety of materials used, by disrespecting imperatives of proportion and scale, and by allowing free-falls between bidimensional and tridimensional space, the maquette becomes a strong object of alternative urban imaginaries.

After the materiality of the maquette was temporarily stabilised, a crucial puzzle remains: how do the lure of concreteness and the co-option by materials work for producing and furthering activist solidarities? Firstly, "Atelierul de urbanism" (The Urbanism Workshop) began with five committed participants, and it attracted around ten more members in just a few months. Secondly, the fascination with the negotiation with materials was visible on the very occasion of building the maquette. The activists started from the idea of the children having full authorship of the maquette, but during the exercise a space of co-authorship emerged, where the adults could get involved without overwriting the creativities of the children. Thirdly, the maquette maintained its capacity to fascinate beyond the time of its production. It furthered its life as an object of political significance when the activists presented the results of the workshop to an audience of local authorities and Romanian and French heritage specialists. The maquette stood as a materialisation of a democratised conception of patrimony.

\section{Toward an Urban Imaginary of Depth}

Once stabilised into its form, the maquette meets us as an intricate "thing" recording co-options, lures and resistances. We caution that what we offer is not a representational reading, or a recording of children's "voices" (Kraftl 2013); instead, what follows is the interpretation of the authors. As Heidegger argues, a "thing" is originally not an object, but a gathering, a particular binding together of the threads of life (Heidegger 1971, p.177; Ingold 2008, p.1807). What is gathered into the maquette? And how is it possible to interpret such gatherings, and to trace the ways they may unblock our urban imaginaries? The epistemological "trick" here is to read the maquette backwards from its apparently stable thingness to the negotiations and entanglements which produced it. This is an instance of a materialism of the encounter at work. 
Firstly, the boldness of the initial plurisensorial exercise preceding the construction of the maquette was inscribed into its making: the environment that the children propose loses its delineations of an "inside" and an "outside" and is envisaged as a "zone of entanglement" (Ingold 2008) of plants, animals, humans, water courses, urban furniture and smaller ephemeral crafts.

Secondly, the maquette bears the capacity to record what Emmanual Levinas (1978) has called "the elemental": the nothings in which things form and which show a dimension of support (such as light or warmth). As Lingis (1994, p.125) writes, "[t]he elemental is not a multiplicity of discrete things successively perceived in their places from vantage points and collated; it is not sensed by a perception which identifies surface patterns. The elemental is sensed in a pure sense of depth, not by an intentional direction of the viewing eye and of the grasping hand aiming at objectives, but by a movement of involution. [...] [i]t is a movement of immersion in a plenum". It is this quality of the maquette of reverting to the elemental that marks a route out of ghostly space. For space to reconcretise we need to travel out of the eye and to grasp how the eye is never enough as a unique horizon of perception: it is this resistance to the gaze that the children teach us in their crafting. The maquette thus prefigures a non-ghostified space, a space of intense use, of desire, and of accomplished commons.

Let us trace further how the elemental emerges on the maquette. What the children give form to in their crafting appeals to all our senses, and defies the reign of a focused eye. They place on the maquette effects of movement and flow (such as the ongoing play of humans and animals or the running water of a fountain), the distinct and plural rhythms of using space (such as the tranquility of a reading break in the park or the effervescence of throwing a ball to one's dog), and even effects of light (such as the rainbow). They materialise the elemental and lead us away from an urban imaginary populated by discrete objects, to an urban imaginary of depth, recuperating the temporal dimension of space and the relations that exist between distinct objects. The objects appear woven into a tissue in constant flow and make up an "environment" (Ingold 2008). Encountering effects of light on the maquette counts as an invitation to subtleness addressed to the urban planner. As Lingis (1994, p.123) tells us "[l]ight is not, like a thing, explorable from different angles and perspectives; it offers no sides, and it is not approached like the surfaces it illuminates. We find ourselves in the light. It is not a substance, supporting and known through its properties; it is luminosity, not a property of any thing, a freefloating adjective." A free-play with materials affords us a spatialisation of such freefloating adjectives. But the maquette contains as well some anchoring "elementals", such as the ground itself. The ground - the depth support of the further negotiation 
with materials - was crafted by the adults participating in the exercise. It involved making plaster, mixing the powder with water, getting the thickness of the mix right, spreading it out, letting it dry and crack in the sun, and repairing some of the cracks with a new layer of material.

On the maquette, the regime of construing boundaries authored by adults and children differed considerably. The children's park is more fluidly connected to the rest of the neighbourhood. It is the adults that initiated the construction of fences, gates, and other separating lines. The only "spatial hint" that was placed on the maquette from the beginning - a blue strip standing for the river that edges the park - was disregarded by the children and taken for "the road home". As if in a dialogue with Michel de Certeau (1984), the children trust their own footsteps in deciding on "credible things" and on "memorable things" of the city. In a surprising challenge of the bird's-eye-view perception, they alternate bidimensional space with tridimensional space. The adults thus learn about fluid boundaries.

There is an overabundance of elements marking a swarming activity in the imagined park. The maquette becomes densely populated by a large collection of singularities, most of which crafted from a mixture of materials. The children's park defies the serialities of the increasingly "insensitive parks" which are emerging throughout the modernist city, repeating the same shapes and modular elements, illattuned to their environment, and governed by the economic rationalities. The emerging "thingness" of the maquette has radiance, sonority, and movement. It recuperates the joy of dwelling and the plural times of lived space.

A crucial question is: how can these qualities of the maquette impact the adult-centric planning culture? Firstly, the experience of being co-opted by materials strengthened bonds on multiple levels and across generations, both between the people involved, and between the people and the spatiality of the park. Secondly, the "thingness" of the maquette, gathering all the negotiations and entanglements that produced it, borders the domain of planning, without being a result of it. It is thoroughly anti-strategic, diverging from most planning processes. Mainstream planning, anchored in the modernist tradition of shaping spaces into a finite product, promotes what Michel de Certeau (1984) would call strategy, by establishing a "proper" place. The locus operandi of strategies is space. But what they miss out is the temporal dimension constitutive of space, which is the locus of tactics. By a clever utilisation of time, tactics present opportunities and introduce play (de Certeau 1984). Both in its constitutive temporality, as produced by intense negotiations, and in its prospective capacity, as an anticipation of the futures of the park, the maquette recovers the temporal dimension of space. Such time-sensitive participatory practices that include the voices of "others" can transform the current 
planning culture. This requires, as Till (2006) suggests, that the planners give away some of their powers of control whilst maintaining their ability to envision. While the vocabulary of participation has made it to institutionalized practices of planning, it has often failed to deliver any substantive results in terms of taking planning out of "specialist hands" and including a polyphony of voices in the process.

In its "thingness" the maquette is also a tool of planning, resembling but not imitating the architectural models usually employed by professionals. It does not represent any given "real" spatiality, like an ordinary model, though it presents a real space; in its three-dimensions it mixes the grammars of bi-dimensional and threedimensional space; it transgresses the interdictions stated by a rational organization of space, though it is not irrational. It resists the "lust to be a viewpoint and nothing more" (de Certeau 1984, p.92). Instead, it gestures toward a planning of depth, which starts from the elemental, the sensuous, the non-discrete, the temporally pluralised. It starts from enunciations of the joy of dwelling, even when recorded in materialities. Thus, its materiality speaks: "I feel good here"; "I feel like running on this path"; "I feel like the grass should be taller here"; "I feel like filling up the driedup fountain".

\section{Conclusions}

Our walk here was one of a materialist sociology that takes disappearances seriously. We moved from a curious disappearance (of space itself) to a reappearance (of space made visible at the works of alternative urban imaginaries). We saw capitalist economy, the juridico-political domain, and the material quotidian as bound together in ways that demand a local thick articulation, and in ways that are never formulaic or temporally fixed (Coole and Frost 2010). We argued that a productive debate on new materialisms - on the resilience and generativity of matter - must preserve the capacity to utter "capitalism does", despite being cautious not to construe totalities that obscure the creativities of quotidian doings. In particular, we showed how capitalism does not merely abstractise space, but it is also capable of operations that are loaded with morbidity: it ghostifies space, it fills it with diffuse death references. No abstraction is ever definitive, as actors find small temporal displacements and fixes to make space leak back into concreteness.

As we spoke, we were driven by a core anxiety, which overflows into a double dystopia: a city space without humans and a city without children, both traversed just by fluxes of capital, which both move and arrest. This core anxiety can ground an important question: how to reconstitute an ecology that includes children, alongside 
other living beings, in the urban space? It can also ground a theoretical pursuit: how to build a strong alliance between social thinkers that allow us to think materialism in the frame of an ecology (such as Gregory Bateson, Félix Guattari, Donna Haraway, or Tim Ingold)? For being able to envisage an ecology, we here started from the ways children materialise the elemental and lead us away from an urban imaginary populated by discrete objects, to an urban imaginary of depth, recuperating the temporal dimension of space and the surprising relations that exist between objects.

\section{Notes}

\footnotetext{
'For a review recent review of the debate on notions of "voice" and "politics" in the field of children's geographies, see Kraftl (2013).

ii In 2001, the discussions on property, which had gone on for over a decade in postsocialist Romania, produced the property law. See Law nr. 10/2001.

iii Contract no. 1326/12.09.2006 between C.N.C.F. „CFR” S.A. through the regional branch CF Cluj, and S.C. S.C.F. - CFR ECOMAX S.A. Cluj.

iv 15 children aged 5 to 14 .
}

\section{References}

Adorno, Theodor. 1978. Minima Moralia: Reflections from Damaged Life. Translated by EFN Jephcott. New York: Verso.

Aitken, Stuart. 2007. "Desarrollo Integral y Fronteras/Integral Development and Borderspaces." Children's Geographies 5: 113-129.

Althusser, Louis, and Étienne Balibar. 1970. Reading Capital. Translated by B Brewster. NLB: London.

Althusser, Louis. 2006. Philosophy of the Encounter: Later Writings, 1978-1987. Translated by GM Goshgarian and edited by F Matheron. New York: Verso.

Amin, Ash, and Nigel Thrift. 2002. Cities: Reimagining the Urban. Cambridge: Polity.

Bateson, Gregory. 1972. Steps to an Ecology of the Mind. Chicago and London: University of Chicago Press.

Benjamin, Walter. 1996. "Old Forgotten Children's Books." In Selected Writings, 1913-1926. Translated by R Livingstone and edited by M Bullock and MW Jennings. Cambridge, MA: Belknap Press of Harvard University Press.

Brown, Bill. 1998. "How to Do Things with Things." Critical Inquiry 24(4): 935-964.

Castoriadis, Cornelius. 1987. The Imaginary Institution of Society. Cambridge: Polity Press. 
Chakrabarty, Dipesh. 2000. Provincializing Europe. Princeton: Princeton University Press.

Coole, Diana, and Samantha Frost, eds. 2010. New Materialisms: Ontology, Agency and Politics. Durham and London: Duke University Press.

De Certeau, Michel. 1984. The Practice of Everyday Life. Berkley and Los Angeles: University of California Press.

De Landa, Manuel. 2000. A Thousand Years of Nonlinear History. New York: Zone Books.

Doel, Marcus. 1999. Poststructuralist Geographies: The Diabolical Art of Spatial Science. Edinburgh: Edinburgh University Press.

Gillespie, Judy. 2013. "Being and Becoming: Writing Children into Planning Theory." Planning Theory 12 (1): 64-80.

Guattari, Félix. 2011. The Machinic Unconscious: Essays in Schizoanalysis. Los Angeles: Semiotext(e).

Haraway, Donna. 2003. The Companion Species Manifesto: Dogs, People and Significant Otherness. Chicago: Prickly Paradigm Press.

Heidegger, Martin. 1971. "Thinking Dwelling Building." In Poetry, Language, Thought, 145-161. New York: Harper and Row.

Horton, John, and Peter Kraftl. 2006. "Not Just Growing Up, but going On : Materials, Spacings, Bodies, Situations." Children's Geographies 4 (3): 259-276.

Ingold, Tim. 2000. The Perception of the Environment. Essays on Livelihood, Dwelling and Skill. London and New York: Routledge.

Ingold, Tim. 2008. "Bringing Things to Life: Creative Entanglements in a World of Materials." Paper presented at Vital Signs: Researching Real Life, University of Manchester, 9 September.

Ingold, Tim. 2011. "Materials against materiality." In Being Alive. Essays on Movement, Knowledge and Description, 19-32. New York: Routledge.

James, Allison, and Adrian L. James. 2004. Constructing Childhood: Theory, Policy and Practice, Basingstoke: Palgrave.

Jones, Owain. 2008. "'True geography [ ] quickly forgotten, giving away to an adultimagined universe'. Approaching the otherness of childhood." Children's Geographies 6 (2): 195-213.

Karaman, Ozan. 2012. "An Immanentist Approach to the Urban." Antipode 44(4): 1287-1306.

Klee, Paul. 1973. Noteboooks, volume 2: The nature of nature. Translated by $\mathrm{H}$ Norden and edited by J Spiller. London: Lund Humphries.

Klooger, Jeff. 2009. Castoriadis: Psyche, Autonomy, Society. Leiden and Boston: Brill.

Kopytoff, Igor. 1986. "The Cultural Biography of Things: Commoditization as Process." In The Social Life of Things: Commodities in Cultural Perspective, edited by Arjun Appadurai, 64-94. Cambridge: Cambridge University Press. 
Kraftl, Peter. 2013. "Beyond 'voice', beyond 'agency', beyond 'politics'? Hybrid Childhoods and Some Critical Reflections on Children's Emotional Geographies." Emotion, Space and Society 9 (November): 13-23.

Kraftl, Peter. 2015. "Alter-Childhoods: Biopolitics and Childhoods in Alternative Education Spaces." Annals of the Association of American Geographers 105 (1): 219-237.

Levinas, Emmanuel. 1978. Existence and Existents. Translated by A Lingis. The Hague: Martinus Nijhoff.

Lingis, Anphonso. 1994. The Community of Those Who Have Nothing in Common. Bloomington and Indianapolis: Indiana University Press.

Lukacs, Georg. 1971. "Reification and the Consciousness of the Proletariat." In History and Class Consciousness: Studies in Marxist Dialetics. Translated by $\mathrm{R}$ Livingstone. London: Merlin Press.

Mannion, Greg. 2007. "Going Spatial, Going Relational: Why 'listening to Children' and Children's Participation Needs Reframing." Discourse: Studies in the Cultural Politics of Education 28 (3): 405-420.

Massey, Doreen B. 2005. For Space. London: Sage.

Matthews, Hugh. 2005. "Rising Four: Reflections on the State of Growing-Up." Children's Geographies 3(3): 271-273.

Mitchell, Katharyne, and Sarah Elwood. 2012. “Mapping Children's Politics: The Promise of Articulation and the Limits of Nonrepresentational Theory." Environment and Planning D: Society and Space 30 (5): 788-804.

Mitrea, Vasile. 2010. "Spre un sistem de spatii verzi." In Cluj-Napoca in proiecte 50 de ani 1960-2010, edited by V Mitrea, E Tudose, A Buzuloiu, E Panescu. Cluj-Napoca: Imprimeria Ardealul.

Petrescu, Doina. 2010. "How to Make a Community as Well as the Space for It." In Evicting the Ghost. Architectures of Survival, edited by Alina Serban. Bucharest: Center for Visual Introspection.

Smith, Neil. 1996. The New Urban Frontier. London: Routledge.

Smith, Richard G, and Marcus Doel. 2011. "Questioning the Theoretical Basis of Current Global-City Research: Structures, Networks, and Actor-Networks." International Journal of Urban and Regional Research 35(1): 24-39.

Thrift, Nigel. 2005. "From Born to Made: Technology, Biology and Space." Trans Inst Br Geogr NS 30: 463-476.

Thrift, Nigel. 2008. Non-representational Theory: Space, Politics, Affect. London: Routledge.

Till, Jeremy. 2006. "The Architect and the Other." Accessed 25 November, 2013. http://www.opendemocracy.net/ecology-landscape/architecture_3680.jsp

Warshak, Richard. 2003. "Payoffs and pitfalls of listening to children." Family Relations, 52: 373 -384. 